\title{
Using Social Media to Enhance ESL Writing Skill among Gen-Z Learners
}

\author{
Nurazimah Aziz, Harwati Hashim*, Melor Md. Yunus \\ Faculty of Education, Universiti Kebangsaan Malaysia, Bangi, Malaysia \\ Email: ^harwati@ukm.edu.my
}

How to cite this paper: Aziz, N., Hashim, H., \& Yunus, M. Md. (2019). Using Social Media to Enhance ESL Writing Skill among Gen-Z Learners. Creative Education, 10, 3020-3027.

https://doi.org/10.4236/ce.2019.1012226

Received: October 16, 2019

Accepted: November 26, 2019

Published: November 29, 2019

Copyright $\odot 2019$ by author(s) and Scientific Research Publishing Inc. This work is licensed under the Creative Commons Attribution International License (CC BY 4.0).

http://creativecommons.org/licenses/by/4.0/

(c) (i) Open Access

\begin{abstract}
English as a Second Language (ESL) in Malaysia faces many challenges due to multicultural and environmental factors such as lack of interactive speaking environment, lack of exposure, and unconvincing of teaching and learning method. Moreover, the evolutions of the generations contribute a great impact to the changes in our education sector especially in terms of teaching and learning process. It is important to understand basic needs and distinctions across generation for developing pedagogy that reaches the unique population. Currently, the wave of latest generation entered and occupied in most sectors including industrial and educational sectors are known and recognised as Generation Z. Therefore, this paper reviews the needs of Gen Z that would be essential in contributing to a successful teaching and learning method in ESL lesson. This paper also discusses further about the strategies utilised by successful language learner among Gen $\mathrm{Z}$ which is the use of social media as a medium of interaction in enhancing writing skill. In conclusion, this study proposes a new alternative in conducting writing activity during ESL lesson for a continuous learning process.
\end{abstract}

\section{Keywords}

Language Learning Strategy (LLS), Instagram, ESL Learners, Interactive Learning, Technology-Enhanced Language Learning

\section{Introduction}

Malaysia is one of the countries colonized by the British Empire; hence it inherits English as a second official language. During colonialism, British rendered English-medium school in urban areas which were established to prepare for a local workforce who would handle and occupy the administration position (Malakolunthu \& Rengasamy, 2012). Since independence in 1957, Malaysia has con- 
stantly been involved in language policy changes. In the early years of the pre-independence era, the changes in the language policies were necessary to illustrate the future of the young nation. These changes were supposed to be fundamental in establishing Malaysia as a multiethnic and multicultural nation. The government intends to make Bahasa Malaysia as a national language of the country while English as a second official language. However, most Malaysians are still facing difficulties in applying the language academically and communicatively.

In this globalised era of borderless information and technology, most of the job seekers agreed that the importance of acquiring the skills of English communication is compulsory to get a job (Zubaidah Awang \& Shaidatul Akma, 2008). However, according to Hashemi (2011) in most countries in the world, majority of the students are not performing well in English especially when English is not used as their first language. The issue arises when students are expected to have a good command of English language even though there is a lack of exposure to the language. Thus, there should be an initiative to encourage language learners to acquire communicative fluency by applying any accessible language learning strategies due to lack of exposure in English language.

\section{Technology in ESL Classroom}

English is the second language being taught in Malaysia. Therefore, MoE has developed the Malaysia Educational Blueprint to provide our students with skills that enable them to acquire the language successfully. Literally, with the vast changes in technology, our life routine also experiences the changes (Hashim, Yunus, \& Embi, 2016). According to Khairunnisa et al. (2018), the demand for workers has declined, however, the need for service and knowledge workers have increased. This affects the learning and schooling method in our education system to meet the requirement of the industry. Due to this, academia is continuously looking at how technology tools can be used in the classroom (Yunus, Salehi, \& Chenzi, 2012; Yunus, Hashim, \& Lubis, 2010; Hashim \& Yunus, 2010) as most of the professional fields were influenced to use it. This evolution contributes to a great challenge and new experience to the educators and policymakers to bring something new to our education system.

Mobile-assisted Language Learning (MALL) initiated as a relevant technology used in classroom in the 1980s (Hashim et al., 2017). The first research was conducted by Twarog and Pereszlenyi (2018) by using a telephone to assist language study. These latest technologies are seen as a new interactive teaching methodology as they are closer to the learners' interest (Aloraini, 2018). Moreover, as long as the learners have access to the device, MALL can be carried out anywhere as an informal or formal lesson. Many empirical studies proved the advantages of using technology are essential to be used in the language classroom (Aloraini, 2018). Learners of the $21^{\text {st }}$-century especially the new generation of learning are attached to the digital world as they are drawn into mobile apps rather than being academically minded. 
It has been agreed that technology should not be regarded as a magic bullet to solve educational problems (Warshauer, 2009). However, it can be used as a powerful tool that can contribute to a positive impact in our education sector. In general view, the use of technology particularly social media allows the students to develop their creativity in learning process by providing a platform with rich and deeper learning environment which are contextual, engaging, and student-owned (Camean \& Haefner, 2002). Latest technologies could influence the way of learning on what, how, and where the learners can learn. According to Azlina et al., (2019), the learning material should provide opportunities for the learners to give feedback by activities that encourage them to check their language achievement. The portability of mobile devices allows students to have easy access to language learning material at all time. However, it has its own educational implications and challenges when it comes to the teaching and learning context. Thus, by taking in technology could be the best platform to create a learning environment that requires active participation, problem-solving and collaboration among peers.

\section{Social Media}

Social media is a web-based service that allows individuals to construct public profile within a bounded system, articulate a list of other users with whom they share the information, and view their list of connections within the system (Boyd \& Ellison, 2007). According to Kaplan \& Haenlein (2010), social media is a group of internet-based application's that build on the ideological and technological foundations and allow the exchange of user-granted content. As technology tools such as social media have vast changes, defining social media has become a challenge and keep evolving according to time. Kusnierek (2015) supported the social media definition by Kaplan \& Haenlein (2010) that defined the same concept but he added a point where social media depends on mobile and web-based technologies to create a highly interactive platform for the users can share, co-create, discuss and modify user-generated content. Meanwhile, Kamel (2016) expanded the definition of social media as computer-mediated tools and applications that give space to create, share, or exchange information, ideas, pictures, and videos virtually and without barriers.

Social media is likely to emerge almost every day with more advanced features. Due to this, Kaplan \& Haelein (2010) conclude there is no systematic way to categorize types of social media. However, they have proposed a systematic classification based on a set of theories in the media research field (social presence and media richness) and social processes (self-presentation and self-discourse). Social presence is related to acoustic, visual, and physical contact between two people, whereas, media richness refers to the amount of information that the media allow to transmit in a given time interval. While self-presentation and self-discourse is an impression and the combination of inclination to develop interactions with others. Thelwall (2009) proposed social media can be classified according to their purposes which are socializing, networking, and 
navigation. Socializing SNS is designed for social communication among members such as Facebook or Instagram, while networking SNS are functioning for non-social interpersonal communication such as LinkedIn, and navigation SNS are likely to help users find a particular type of information such as Flickr and YouTube. This has been supported by Manca \& Ranieri (2015) which they classified social media according to purposes but only into three categories which are educational, professional or research, and social interaction.

Therefore, there are significant benefits associated with the application of social media in delivering educational outcomes, facilitate supportive relationship, identify formation, and promoting self-esteem (Collin, Rahilly, Richardson, \& Third, 2011). Social media have been recognized to shift the role of educators from a gatekeeper to a facilitator, provide learners with educational information, support social interaction and educational communication, contribute a platform for expressing ideas, support collaborative learning and support reflective learning (Chen, Diao, \& Zhang, 2011). These studies were supported by a focus group of research which revealed that social media could be applied to spread announcement or information, provide comprehend communication, encourage discussion, motivate people to share ideas, enable restudying, and provide self-evaluation (Tudini, 2015).

\section{Writing Skill}

Ministry of Education (MoE) has included bilingualism programme on their agenda and has supported the citizens to be bilingual or multilingual. A learner needs to know to write in order to deliver or to relay information, this is where the skill is required to the language so that the other party would be able to comprehend the message. The ministry always put high hopes on learners to be nurtured by positive school's environment and have the experience in second language acquisition. Learners' written works should be applied as supplementary material for them (Ahmad Sukor \& Embi, 2017). Hence, it is crucial to return into the classroom where the learners learn the second language in order to ensure them able to compete.

Issues related to English proficiency and competency have become critical in Malaysian education system. Most of the learners are still not proficient in English language especially those who are in rural area even though they have learned the language for eleven years in primary and secondary school. The non-native English learners are preferred to use their respective mother tongue instead of converse in English, thus it contributes difficulties for them to write when they don't know how to speak and use the language (Lee \& Yunus, 2016). This could be most probably they are more comfortable using their mother tongue or first language in their daily conversation and it becomes difficult for them to express their feelings or opinion because they need to struggle in constructing a sentence in English language. Thus, in Malaysia Education Blueprint, Ministry of Education has encouraged teachers to be more creative in planning 
language lesson that would be interactive and facilitate the students to improve their skills especially in writing for the targeted language. So, when they leave the school, they would acquire world-class knowledge and skills in the targeted language and able to survive in the global market (MoE, 2013). As a consequence, the learners would have more opportunities to use the language confidently in the examination or in their daily life.

\section{Generation Z (Gen-Z)}

Generation $\mathrm{Z}$ or known as Gen-Z is the cohort after the Millennials which born from the mid-1990s to the early 2000s (Forbes, 2015). They are often children of Generation X but some also have parents who are Millennials. They appear to be more technology readily since their upbringing environment that used mobile devices. Majority of Gen-Z used the Internet since a young age and they are comfortable with technology and social media. Their generation has a "digital bond to the Internet" and it may assist them to escape from emotional and mental struggles they face offline. Social media has become integrated into most of Gen-Z daily life where they constantly access to mobile technology. As a consequence, mobile technology has developed an online relationship to become a new generational norm. There are relative studies about Generation $\mathrm{Z}$ that support this generation appear to learn more via observation and experiential practise. They tend and rely more on Internet search engines and videos rather than refer to text-books or manuals (Bobbi \& Kelly, 2017). Generation Z are eager to learn but in a way that keep pace and align with the digital age.

\section{Conclusion}

There are tremendous benefits in cooperating social media and ESL/EFL for both instructors and learners. However, the challenges and limitations need to be taken into consideration as most of the learners were found hesitant to use English in their writing due to psychological factors where they do not have the motivation and lead to low self-confidence. Therefore, the instructor needs to recognize the basic needs and differences of generation as learners, their proficiency and be aware of their limitation in order to develop their learners' learning experiences. According to Lomicka \& Lord (2009), the instructors can be creative by creating pedagogically activities to foster a linguistic and cultural environment in their classes so that the learners can engage in with targeted language, L2 in ways or method impossible previously. Other challenges and limitations should be carefully addressed such as management of personal information and privacy, the risk of predation, cyberbullying, and safety should be taken into account.

This method of teaching is a major change and challenge to the traditional instructional methods. It is one of the crucial moves that the government needs to take by setting up their policies and steps in placing dynamic transition and evolution from traditional to technology. It can be done in terms of assisted 
learning environment, innovative uses of media social inside and outside of the classroom and evaluation of ESL teachers as well as students while integrating technology and social media into teaching and learning practices. The Ministry of Education (MoE) should ensure that social media can be a tool to be used educationally in meaningful ways. The cultural values and social norms of the social media stakeholders also should be taken into account when integrating SNS into ESL classroom. Obstacles of cultural and social factors should be addressed to overcome the barriers that prevent the instructors and learners from using and adopting SNS in their learning process. The instructors should be provided with training and professional development to assist and facilitate them in applying SNS throughout their teaching practices.

Social media was found as the best tool to engage the learners with different proficiency to actively interact with their peers by using English as well as to motivate them to learn the language. The application of technology should be embedded in pre-service as well as in serving the teaching training course. Besides that, the institution and school administration should support the teachers or educators by providing technical and pedagogical guidance. The government and institution should also explain the policy to the parents; thus, the parents will not feel hesitate to allow their children to learn through media social. This could be a good collaboration among teachers and parents to educate the learners together. More additional targeted and specific research can be conducted on learners' learning styles to maximize the benefits of social media and to explore the best practice to be applied throughout the learning process.

In conclusion, collaborative activities which require group discussion through media social also were found as a fit medium to generation $\mathrm{Z}$ in order to increase their readiness to use English by freely expressed their opinion and thought. Throughout this medium, they were also managed to hold the discussion even though they were seen as not confident to start writing in English. Moreover, via this medium could enable the instructors or teachers to help learners become more effective by creating dynamic learning environment. Thus, social media is agreed as one of the best platforms to instil learners' braveness in using English language to convey their messages accurately. Besides, we can drive the generation to use media social towards a positive way. It seems to be an ideal medium for transactional learning and was found as a crucial platform in this age of technology especially among Generation Z.

\section{Funding}

This research was supported by the grant from Universiti Kebangsaan Malaysia KRA-2018-044 and PP-FPEND-2019.

\section{Conflicts of Interest}

The authors declare no conflicts of interest regarding the publication of this paper. 


\section{References}

Ahmad Sukor, H. \& Embi, M. A. (2017). Development and Evaluation of a Reading Module for Form Two Students. Prosiding Seminar Penyelidikan Pendidikan Kebangsaan, 920-929.

Aloraini, N. (2018). Investigating Instagram as an EFL Learning Tool. Arab World English Journal (A WEJ), 4, 174-184. https://doi.org/10.24093/awej/call4.13

Aziz, A. A., Narayanasamy, J., Mohamad, M., \& Hameed, H. A. (2019). Student-Teachers' Experiences in Creating Oral History Texts. 3L: The Southeast Asian Journal of English Language Studies, 25, 79-89. https://doi.org/10.17576/3L-2019-2503-06

Boyd, D. M., \& Ellison, N. B. (2007). Social Network Sites: Definition, History, and Scholarship. Journal of Computer-Mediated Communication, 13, 210-230. https://doi.org/10.1111/j.1083-6101.2007.00393.x

Carmean, C., \& Haefner, J. (2002). Mind over Matter: Transforming Course Management Systems into Effective Learning Environments. EDUCAUSE Review, 37, 27-37.

Chen, S., Diao, Y., \& Zhang, J. (2011). Social Media: Communication Characteristics and Application Value in Distance Education. In Second International Conference on Electrical and Control Engineering (pp. 6774-6777). Piscataway, NJ: IEEE.

https://doi.org/10.1109/ICECENG.2011.6056919

Collin, P., Rahilly, K., Richardson, I., \& Third, A. (2011). The Benefits of Social Networking Services: A Literature Review. Melbourne: Cooperative Research Centre for Young People, Technology and Wellbeing.

Hashim, H., \& Yunus, M. M. (2010). Learning via ICT: “TELL ME MORE”. International Journal of Learning, 17, 211-224.

Hashim, H., Yunus, M. M., \& Embi, M. A. (2016). Pre-University English as Second Language (ESL) Learners' Attitude towards Mobile Learning. Creative Education, 7, 1147-1153. https://doi.org/10.4236/ce.2016.78119

Hashim, H., Yunus, M. M., Embi, M. A., \& Ozir, N. A. M. (2017). Mobile-Assisted Language Learning (MALL) for ESL Learners: A Review of Affordances and Constraints. Sains Humanika, 9, 45-50. https://doi.org/10.11113/sh.v9n1-5.1175

Kamel, S. (2016). Electronic Commerce Challenges and Opportunities in Egypt. In Encyclopedia of E-Commerce Development, Implementation, and Management (pp. 12291240). Hershey, PA: IGI Global. https://doi.org/10.4018/978-1-4666-9787-4.ch088

Kaplan, A. M., \& Haenlein, M. (2010). Users of the World, Unite! The Challenges and Opportunities of Social Media. Business Horizons, 53, 61.

https://doi.org/10.1016/j.bushor.2009.09.003

Khairunnisa, W. I., Aziz, N., Zakaria, N., \& Md Yunus, M. (2018). Enhancing Speaking Skill among Students in ESL Lesson through the Utilizing of Instagram.

Kusnierek, A. (2015). Developing Students' Speaking Skills through Role-Playing. World Scientific News, 7, 73-111.

Lee, P., \& Yunus, M. M. (2016). Successful Language Learning Strategies Used by Successful Year 5 English as a Second Language (ESL) Learners. Proceeding of ICECRS, 1, 539-548. https://doi.org/10.21070/picecrs.v1i1.523

Lomicka, L., \& Lord, G. (2009). The Next-Generation: Social Networking and Online Collaboration in Foreign Language Learning. San Marcos, TX: Computer-Assisted Language Instruction Consortium (CALICO).

Manca, S., \& Ranieri, M. (2015). Implications of Social Network Sites for Teaching and Learning. Where We Are and Where We Want to Go. Education and Information Technologies, 22, 605-622. https://doi.org/10.1007/s10639-015-9429-x 
Ministry of Education MoE Malaysia (2013). Malaysian Education Blueprint: 2013-2025 (Preschool to Post-Secondary Education). Putrajaya: Kementerian Pendidikan Malaysia.

Thelwall, M. (2009). Social Network Sites: Users and Uses. In: M. Zelkowitz (Ed.), $A d$ vances in Computers 76 (pp. 19-73). Amsterdam: Elsevier. https://doi.org/10.1016/S0065-2458(09)01002-X

Tudini, V. (2015). Interactivity in the Teaching and Learning of Foreign Languages: What It Means for Resourcing and Delivery of Online and Blended Programmes. The Language Learning Journal, 46, 132-145. https://doi.org/10.1080/09571736.2014.994183

Warshauer, M. (2009). Foreword. In M. Thomas (Ed.), Handbook of Research on Web 2.0 and Second Language Learning. Hershey, PA: Information Science.

Yunus, M. M., Hashim, H., Embi, M. A., \& Lubis, M. A. (2010). The Utilization of ICT in the Teaching and Learning of English: "Tell Me More". Procedia-Social and Behavioral Sciences, 9, 685-691. https://doi.org/10.1016/j.sbspro.2010.12.218

Yunus, M. M., Salehi, H., \& Chenzi, C. (2012). Integrating Social Networking Tools into ESL Writing Classroom: Strengths and Weaknesses. English Language Teaching, 5, 42-48. https://doi.org/10.5539/elt.v5n8p42 